\title{
Robert Ptak
}

\section{Eucharystia - tajemnica wiary powierzona Kościołowi : adhortacja apostolska Benedykta XVI "Sacramentum caritatis" w świetle kanonu 897}

Prawo Kanoniczne : kwartalnik prawno-historyczny 50/3-4, 291-308

2007

Artykuł został zdigitalizowany i opracowany do udostępnienia w internecie przez Muzeum Historii Polski w ramach prac podejmowanych na rzecz zapewnienia otwartego, powszechnego i trwałego dostępu do polskiego dorobku naukowego i kulturalnego. Artykuł jest umieszczony w kolekcji cyfrowej bazhum.muzhp.pl, gromadzącej zawartość polskich czasopism humanistycznych i społecznych.

Tekst jest udostępniony do wykorzystania w ramach dozwolonego użytku. 
KS. ROBERT PTAK SCJ

Uniwersytet Kardynała Stefana Wyszyńskiego w Warszawie

\section{EUCHARYSTIA - TAJEMNICA WIARY POWIERZONA KOŚCIOŁOWI ADHORTACJA APOSTOLSKA BENEDYKTA XVI SACRAMENTUM CARITATIS W ŚWIETLE KANONU 897}

Treść: Wstęp. 1. Godność Najświętszej Eucharystii. 2. Tajemnica Eucharystii. 3. . Eucharystia życiem Kościoła. 4. Eucharystia a pozostałe sakramenty. Zakończenie.

\section{Wstęp}

Kodeks Prawa Kanonicznego ${ }^{1}$ z 1983 roku poświęca wiele miejsca uświęcającemu zadaniu Kościoła (księga IV). Zadanie to realizuje się przede wszystkim poprzez sakramenty, wśród których szczególne miejsce zajmuje Eucharystia, określana jako Najświętszy Sakrament. O wyjątkowości tego sakramentu mówi w sposób syntetyczny kanon 897: „Najbardziej czcigodnym sakramentem jest Najświętsza Eucharystia, w której sam Chrystus Pan jest obecny, ofiaruje się oraz jest spożywany i dzięki której Kościól ustawicznie żyje i wzrasta. Ofiara eucharystyczna, pamiątka śmierci i zmartwychwstania Pana, w której uwiecznia się Ofiara Krzyża, jest szczytem i źródłem całego kultu oraz życia chrześcijańskiego; oznacza ona i sprawia jedność Ludu Bożego, przez nią buduje się Ciało Chrystusa. Pozostałe bowiem sakramenty i wszystkie kościelne dzieła apostolatu mają związek z Najświętszą Eucharystią i ku niej są ukierunkowane."

Adhortacja apostolska Benedykta XVI Sacramentum Caritatis o Eucharystii ${ }^{2}$, wydana w 2007 roku, zawiera wiele wątków, które odzwierciedlają treść cytowanego kanonu. W papieskim doku-

\footnotetext{
' Dalej: KPK.

${ }^{2}$ Dalej: SacCar.
} 
mencie, zwłaszcza w pierwszej części zatytułowanej „Eucharystia tajemnica wiary", odnajdujemy kilka tematów, które łączą się z kanonem 897 i pozwalają stwierdzić, iż Eucharystia jest tajemnicą wiary powierzoną Kościolowi. To wyjątkowe i niepowtarzalne znaczenie Najświętszego Sakramentu w życiu Kościoła ma swoje źródło przede wszystkim w stwierdzeniu, iż sam Chrystus Pan jest obecny w tym sakramencie. Co więcej, Jezus obecny w Eucharystii ponawia swoją ofiarę dokonaną na krzyżu i staje się pokarmem na życie wieczne. Jego obietnica dotycząca pozostania z uczniami aż do skończenia czasów realizuje się w Kościele, który dzięki Eucharystii żyje i ustawicznie wzrasta. Życie Kościoła, wszystkich jego członków zgromadzonych w jednym ludzie Bożym, znajduje swój szczyt i źródło kultu właśnie w Eucharystii, która jest sercem Mistycznego Ciała Chrystusa. Również pozostałe sakramenty, ustanowione przez Jezusa i powierzone Kościołowi, żyją dzięki Eucharystii i do niej zmierzają.

Warto przeanalizować w świetle kanonu 897 zagadnienia poruszane w pierwszej części Sacramentum Caritatis, skupione wokół punktów: 1. Godność Najświętszej Eucharystii. 2. Tajemnica Eucharystii. 3. Eucharystia życiem Kościoła. 4. Eucharystia a pozostałe sakramenty.

\section{Godność Najświętszej Eucharystii - w niej sam Chrystus Pan jest obecny}

Podstawowym stwierdzeniem kanonu 897 są słowa mówiące o obecności Chrystusa, a w konsekwencji całej Trójcy Świętej, w Sakramencie Eucharystii - to zaś decyduje o jej wyjątkowej godności. Magisterium Kościoła jednoznacznie wypowiada się na ten temat m.in. poprzez soborowe nauczanie. Sobór Trydencki (1551 r., sesja XIII), systematyzując naukę Kościoła dotyczącą sakramentów i odrzucając błędne poglądy, potwierdził, że obecność Jezusa Chrystusa w Eucharystii nie jest symboliczna ani czasowa, lecz substancjalna, realna i stała ${ }^{3}$. Ta wiara eucharystyczna Kościoła, jak mówi Be-

\footnotetext{
${ }^{3}$ Sobór stwierdza, że pod postaciami chleba i wina obecny jest „prawdziwie, rzeczywiście i substancjalnie” nasz Pan, Jezus Chrystus, „prawdziwy Bóg i prawdziwy czlowiek”. Jest On tutaj obecny sakramentalnie „w swojej substancji”, co prawda w sposób tajemniczy, ale dla Boga możliwy i dający się ująć ludzką myślą dzięki świattu wiary (Por. Breviarium Fidei. Wybór doktrynalnych wypowiedzi Kościota, Księgarnia św. Wojciecha Poznań 1997, VII, 289, s. 399).
} 
nedykt XVI, wyraża się w słowach wypowiadanych zaraz po konsekracji „Oto wielka tajemnica wiary”, bowiem substancjalna przemiana chleba i wina w Ciało i Krew Chrystusa staje się rzeczywistością, która przekracza wszelkie ludzkie zrozumienie i staje się „streszczeniem i podsumowaniem calej naszej wiary" wiara i sakramenty stanowią dwa wzajemnie uzupełniające się wymiary życia religijnego, a Eucharystia stanowi ciągle odradzające się centrum życia Kościola. Historia Kościoła potwierdza natomiast, iż żywa wiara eucharystyczna ludu Bożego mocniej wpływa na uczestnictwo w życiu Kościoła i pogłębia zaangażowanie w pełnienie misji powierzonej mu przez Chrystusa ${ }^{5}$.

Podkreślając godność Najświętszego Sakramentu, Benedykt XVI przywołuje rozmowę Jezusa z Nikodemem: o Bogu, który tak umilował świat, że dał swego Syna Jednorodzonego, aby każdy, kto w Niego wierzy, dostąpił zbawienia i osiągnął życie wieczne (por. J 3,16-17). Fundamentem wiary eucharystycznej staje się więc tajemnica samego Boga i Jego miłości, mającej źródło w miłości trynitarnej ${ }^{6}$. Jezus obecny w Eucharystii daje swoje Ciało i swoją Krew, które są wyrazem całej Jego Osoby, Jego życia i zleconego mu posłannictwa. W Eucharystii Jezus staje się darem Ojca. Przekonuje nas o tym cud rozmnożenie chleba i zapewnienie Jezusa, że dopiero Jego Ojciec da prawdziwy chleb z nieba (por. J 6,32-33). Chleb ten utożsamiany jest $z$ ciałem Chrystusa: „Ja jestem chlebem żywym, który zstąpił z nieba. Jeśli kto spożywa ten chleb, będzie żył na wieki. Chlebem, który Ja dam, jest moje ciało za życie świata" (J 6,51).

Bóg, będąc doskonałą komunią między Ojcem, Synem i Duchem Świętym, odsłania przed człowiekiem swój zamysł miłości i zaprasza go do wspólnoty ze sobą. Dzieli się z człowiekiem swoim wewnątrztrynitarnym życiem, uwzględniając ludzką kondycję, naznaczoną grzechem i słabością. W chlebie i winie, pod których postaciami Chrystus całkowicie się daje, Boże życie dociera do nas i udziela się nam w formie sakramentu'. To prawda, że uczestnictwo czlowieka w życiu samego Boga w jakimś stopniu realizuje się

\footnotetext{
${ }^{4}$ Katechizm Kościola Katolickiego, 1327 (dalej: KKK).

${ }^{5}$ Por. SacCar 6.

- Por. SacCar 7.

3 Por. SacCar 8.
} 
poprzez fakt stworzenia - otrzymania ożywczego tchnienia będącego zadatkiem nieśmiertelności. Jednak dopiero poprzez śmierć i zmartwychwstanie Chrystusa oraz zesłanie Ducha Swiętego człowiek w pełni staje się uczestnikiem Bożego życia. Dopiero Jezus Chrystus, który przez „Ducha wiecznego złożył Bogu samego siebie jako nieskalaną ofiarę" (Hbr 9,14), udziela nam tego samego życia w darze eucharystycznym. Dar ten, całkowicie bezinteresowny, staje się wypelnieniem zapowiedzi i obietnic Bożych. Kościół otrzymuje tę tajemnicę wiary, by ją celebrować i adorować, a przez to uczestniczyć w niej przez łaskę wybrania ${ }^{8}$.

\section{Tajemnica Eucharystii - Chrystus Pan ofiarowuje się oraz jest spożywany}

Adhortacja Sacramentum Caritatis stwierdza, iż godność Najświętszego Sakramentu wyplywa z faktu obecności w nim samego Jezusa Chrystusa, a z Nim całej Trójcy Świętej. Tajemnica Eucharystii nie wyczerpuje się jednak w przebywaniu Boga w bliskości czlowieka, ale wyraża się również w wymiarze ofiarniczym, o którym przypomina kanon 897. Ofiara Jezusa prowadzi do zawarcia nowego i wiecznego Przymierza we krwi Baranka (por. Łk 22,20), która została przelana w czasie Jego męki. Nowe Przymierze zostało przypieczętowane śmiercią Jezusa na krzyżu, gdzie w doskonałej ofierze złożył On Ojcu samego siebie. Benedykt XVI, nawiązując do tego wydarzenia, mówi: „w Jego śmierci na krzyżu dokonuje się owo zwrócenie się Boga przeciwko samemu sobie, poprzez które On ofiarowuje siebie, aby podnieść człowieka i zbawić go - jest to miłość wyrażona w najbardziej radykalnej formie".

Eucharystia staje się więc doskonalą formą ofiarowania się Chrystusa za nasze grzechy. Ilekroć jest ona sprawowana, rzeczywiście staje się nowym Przymierzem i - co ważne - Przymierzem wiecznym, zgodnie z obietnicą Chrystusa, iż pozostanie On z nami, aż do skończenia świata. Podczas każdej celebracji Mszy św. słyszymy słowa: „Oto Baranek Boży, który gładzi grzechy świata. Blogoslawieni, którzy zostali wezwani na Jego ucztę"10. Jezus jest praw-

\footnotetext{
${ }^{8}$ Por. tamże.

${ }^{9}$ Benedykt XVI, Encyklika Deus caritas est, 12 (dalej: DCE).

${ }^{10}$ Mszal rzymski dla diecezji polskich (wydanie pierwsze), Pallottinum Poznań 1986, s. $375^{*}$ (dalej: MR).
} 
dziwym Barankiem Paschalnym, który dobrowolnie złożył za nas w ofierze samego siebie, ustanawiając w ten sposób nowe i wieczne Przymierze. Eucharystia zawiera w sobie tę radykalną nowość, która jest nam przypominana w każdej celebracji ${ }^{11}$.

Ustanowienie Eucharystii w czasie trwania Ostatniej Wieczerzy wskazuje na kontekst obrzędowej uczty, która stanowiła przypomnienie istotnego wydarzenia kształtującego tożsamość Izraela, tj. uwolnienia z Egiptu. Wieczerza paschalna, jako pamiątką przeszłości, przekształca się w wydarzenie profetyczne, będące zapowiedzią przyszlego uwolnienia, tym razem spod władzy grzechu. Otwiera się w ten sposób droga do głębszego, bardziej radykalnego, powszechnego i definitywnego zbawienia. Jezus, ustanawiając sakrament Eucharystii, „antycypuje i włącza w nią ofiarę krzyża i zwycięstwo zmartwychwstania. Równocześnie objawia się jako prawdziwy baranek złożony w-ofierze i przewidziany w zamyśle Ojca przed założeniem świata (...). Umiejscawiając swój dar w tym kontekście, Jezus objawia zbawczy sens swojej śmierci i zmartwychwstania, tajemnicy, która staje się rzeczywistością odnawiającą historię oraz caly kosmos"12. Ustanowienie przez Jezusa Eucharystii w perspektywie czekającej Go śmierci łączy ją $z$ najwyższym aktem miłości oraz $z$ definitywnym wyzwoleniem ludzkości od zła - dzięki ofierze złożonej za wielu - oraz z nakazem, by czynić to na Jego pamiątkę (por. Łk 22,19; 1 Kor 11,25).

Polecenie to wyraża również prośbę, by odpowiedzieć na Jego dar i by Go uobecniać na sposób sakramentalny. Zawarte jest również w tych słowach oczekiwanie, że Kościół, zrodzony z ofiary Chrystusa złożonej przez Niego na krzyżu, przyjmie ten dar i, wsłuchany w Ducha Świętego, nada mu liturgiczną formę. Eucharystia, jako Pamiątka, nie oznacza prostego powtarzania gestów i słów z Ostatniej Wieczerzy, ale wprowadza radykalną nowość chrześcijańskiego kultu. Jak powie Benedykt XVI, Eucharystia włącza nas w akt ofiarniczy Jezusa, gdzie nie tylko otrzymujemy, w sposób statyczny Logos wcielony, ale zostajemy włączeni w dynamikę Jego ofiary - On włącza nas w siebie samego ${ }^{13}$. To substancjalne „przekształcenie chleba i wina w Jego Ciało i Jego Krew wnosi do wnę-

\footnotetext{
${ }^{11}$ Por. SacCar 9.

${ }^{12}$ SacCar 10.

${ }^{13}$ Por. DCE 13; Tenże, Homilia wygloszona w Marienfeld (21.08.2005), „L'Osservatore Romano" (wyd. pol.) 2005, nr 10 (277), s. 26.
} 
trza stworzenia fundament radykalnej przemiany, coś w rodzaju nuklearnego rozszczepienia, by użyć znanego dziś obrazu, wnikającego w najskrytszy poziom bytu, przemiany mającej za cel wywołanie procesu przekształcenia rzeczywistości, którego kresem ostatecznym będzie przemienienie całego świata, aż do stanu, w którym Bóg stanie się wszystkim we wszystkich (por. 1Kor 15,28)"14.

Tajemnica Eucharystii wiąże się więc $z$ substancjalną obecnością Chrystusa, który pod postaciami chleba i wina ofiarowuje się Ojcu za nasze grzechy - jako prawdziwy Baranek Paschalny. W Nim zostaje zawarte nowe Przymierze, a Jego krew, raz wylana za nas na krzyżu, nieustannie staje się znakiem tego Przymierza. Jest ono odnawiane w każdej celebracji eucharystycznej. Eucharystia staje się więc ofiarą i ucztą, o czym przypomina nam prefacja o Najświętszej Eucharystii: „On [Chrystus] sam jako prawdziwy i wieczny Kaplan, ustanawiając obrzęd wiekuistej Ofiary, pierwszy się Tobie oddał w zbawczej Ofierze i nam polecił ją składać na swoją pamiątkę. Jego Ciało za nas wydane umacnia nas, gdy je spożywamy, a Krew za nas wylana obmywa nas, gdy ją pijemy"15.

\section{Eucharystia życiem Kościoła - dzięki niej Kościół ustawicznie żyje i wzrasta}

Słowa, iż „Najświętsza Eucharystia, w której sam Chrystus Pan jest obecny, ofiaruje się oraz jest spożywany"16 znajdują swoje dopełnienie w stwierdzeniu dotyczącym życia i wzrostu ustanowionego przez Chrystusa Kościoła. Sakrament Eucharystii staje się niewyczerpanym źródłem życia Kościoła i najważniejszym czynnikiem decydującym o jego nieustannym wzrastaniu. Ukazuje również tę wyjątkową relację, jaka zachodzi między Jezusem, ustanowionym przez Niego Kościołem, i każdym wierzącym, przez chrzest włączonym do tej Bosko-ludzkiej wspólnoty. Chrystus w ofierze Krzyża zrodził Kościół - jako swoją Oblubienicę i swoje Ciało ${ }^{17}$. Istnieje

\footnotetext{
${ }^{14}$ SacCar 11.

${ }^{15}$ MR, s. $63^{*}$.

${ }^{16}$ KPK kan. 897.

17 Ojcowie Kościoła ukazują związek między utworzeniem Ewy z boku śpiącego Adama (por. Rdz 2,21-23) a Nową Ewą - Kościołem, zrodzonym z otwartego boku Chrystusa, pogrążonego we śnie śmierci: z przebitego boku, pisze św. Jan, wypłynęła krew i woda (por. J 19,34), symbol sakramentów (por. II Sobór Watykański, Lumen gentium, 3 - dalej: KK).
} 
więc przyczynowy związek pomiędzy ofiarą Chrystusa, Eucharystią i Kościolem, który Jan Paweł II ujmuje w stwierdzeniu, iż Kościół „żyje dzięki Eucharystii”"

Przywołując słowa św. Jana: „On pierwszy nas umilowal” (1 J 4,19), w sprawowaniu każdej Eucharystii podkreślamy pierwszeństwo daru otrzymanego od Chrystusa. Początek Kościola wiąże się $\mathrm{z}$ ustanowieniem Eucharystii nie tylko w aspekcie czasowym, ale także i bytowym, czyli wybrania nas i umiłowania jeszcze przed zatożeniem świata (por. Ef 1,4). Sakrament Eucharystii jest, krótko mówiąc, Chrystusem, który nam się daje, budując nas nieustannie jako swoje Ciało. Stąd też podstawowa prawda o wzajemnej relacji panującej pomiędzy Eucharystią, która buduje Kościól, i samym Kościołem, który sprawuje Eucharystię ${ }^{19}$, zawarta jest w stwierdzeniu: „Kościól może celebrować i adorować tajemnicę Chrystusa obecnego w Eucharystii właśnie dlatego, że sam Chrystus dal się w niej pierwszy poprzez ofiarę Krzyża. Możliwość czynienia Eucharystii przez Kościól jest całkowicie zakorzeniona w darze, jaki Chrystus złożył z samego siebie"zo.

Mówiąc o Eucharystii jako o podstawowej zasadzie życia i wzrastania Kościoła, nie sposób pominąć zagadnienia komunii kościelnej. Chrystus, składając za nas w ofierze siebie samego, zapowiedzial tajemnicę Kościoła - wspólnoty jedności. Przypomina nam o tym choćby prośba z II modlitwy eucharystycznej: ,aby Duch Święty zjednoczył nas wszystkich, przyjmujących Ciało i Krew Chrystusa"21. Pomaga to zrozumieć, że sakrament Eucharystii buduje jedność wszystkich wiernych. O tej wyjątkowej relacji pomiędzy Eucharystią i communio przypomniał także Jana Paweł II, mówiąc o Pamiątce Chrystusa jako o ,najwyższym sakramentalnym wyrazie komunii w Kościele"22. Jedność ta ma swoje ucieleśnienie we wspólnotach chrześcijańskich i odnawia się w celebracji eucharystycznej, która jednoczy je i nadaje im charakter Kościołów partykularnych, „uformowanych na wzór Kościoła powszechnego, w których istnieje i z których się składa jeden i jedyny Kościół katolicki”23.

\footnotetext{
${ }^{18}$ Jan Paweł II, Encyklika Ecclesia de Eucharistia, 1 (dalej: EE).

${ }^{19}$ Por. Jan Paweł II, Encyklika Redemptor hominis, 20.

${ }^{20}$ SacCar 14.

${ }^{21}$ MR, s. $318^{*}$.

${ }^{22} \mathrm{EE} 38$.

${ }^{23} \mathrm{KK} 23$.
} 
Rzeczywistość jednej Eucharystii, sprawowanej w każdej diecezji w jedności z własnym biskupem, pozwala zrozumieć, jak Kościoły partykularne trwają w Kościele powszechnym i ciągle się z niego rodzą, czerpiąc witalne siły do swego rozwoju i wzrastania. Jedyność Mistycznego Ciała Chrystusa, którym jest jeden i niepodzielny Kościól, wyplywa z jedyności i niepodzielności eucharystycznego Ciała Chrystusa Pana. W konsekwencji z tego eucharystycznego centrum wynika otwartość każdej celebrującej wspólnoty, każdego Kościoła partykularnego, który staje się jakby otwartymi ramionami Pana, obejmującymi i włączającymi ochrzczonych w Jego jedyne i niepodzielne Ciało ${ }^{24}$. Z tej racji w celebracji Eucharystii żaden wierny nie jest kimś obcym, lecz znajduje się w swoim Kościele, to znaczy w Kościele Chrystusowym. Oblicze Eucharystii - jako fundamentu komunii kośclelnej - podkreśla jej znamię katolickości, czyli powszechności. Jak zaznacza to Benedykt XVI, zaakcentowanie eucharystycznych korzeni komunii kościelnej tworzy szansę dialogu ekumenicznego z Kościołami i Wspólnotami kościelnymi, które nie są w pelnej komunii ze Stolicą Piotrową. Eucharystia tworzy więź jedności pomiędzy Kościołem katolickim a Kościołami prawosławnymi, które zachowały autentyczną i pełną naturę tajemnicy tego sakramentu. Także dialog ze Wspólnotami zrodzonymi z reformacji może rozwijać się w oparciu o mocne podkreślenie kościelnego charakteru Eucharystiii ${ }^{25}$.

Widzimy więc, że Eucharystia stanowi element konstytutywny istnienia, działania i wzrostu Kościoła. Warto zauważyć, iż chrześcijanie pierwszych wieków, używając wyrażenia Corpus Christi, mieli na myśli po pierwsze ciało zrodzone z Dziewicy Maryi, po drugie Ciało eucharystyczne i - wreszcie - to Ciało, którym jest Kościół. Potwierdza to istnienie nierozerwalnej więzi między Chrystusem i Kościołem, w której Eucharystia stanowi najgłębszy wyraz jedności wiernych i fundamentalną zasadę kościelnej komunii.

\footnotetext{
${ }^{24}$ Por. Kongregacja Nauki Wiary, List o niektórych aspektach Kościola pojętego jako komunia Communionis notio (28.05.1992), 11: AAS 85 (1993), 844-845.

${ }^{25}$ Por. SacCar 15.
} 


\section{Eucharystia a pozostałe sakramenty}

- Ofiara eucharystyczna jest szczytem i źródlem calego kultu oraz życia chrześcijańskiego; oznacza ona i sprawia jedność ludu Bożego, przez nią buduje się Ciało Chrystusa

Sakramentalność Kościola. Kanon 897, stawiając Eucharystię w centrum życia Kościoła, odzwierciedla soborowe nauczanie, mówiące, iż „pozostałe (...) sakramenty, tak jak i wszystkie kościelne posługi i dzieła apostolstwa, wiążą się ze świętą Eucharystią i ku niej zmierzają. W najświętszej Eucharystii zawiera się bowiem całe dobro duchowe Kościoła, to znaczy sam Chrystus, nasza Pascha i Chleb żywy, który przez swoje ożywione przez Ducha Świętego i ożywiające Ciało daje życie ludziom i w ten sposób zaprasza i pobudza, żeby samych siebie, swoją pracę i wszystkie rzeczy stworzone wraz z Nim składali w ofierze"26. Użycie określenia „całe dobro duchowe Kościoła” w odniesieniu do Najświętszego Sakramentu ma swoje źródło w przyjętej przez sobór koncepcji Kościoła, będącego w Chrystusie niejako sakramentem, czyli wewnętrznym znakiem zjednoczenia z Bogiem i jedności całego rodzaju ludzkiego ${ }^{27}$. Benedykt XVI, przytaczając słowa św. Cypriana, określa Kościól jako lud zgromadzony w jedności Ojca, Syna i Ducha Świętego, co czyni tę wspólnotę sakramentem trynitarnej komunii ${ }^{28}$.

Soborowa konstytucja o Kościele podkreśla sakramentalny charakter Kościoła, ale wskazuje również na jego powszechnośćc ${ }^{24}$. Ten właśnie uniwersalny charakter nadany przez Chrystusa zbawczej wspólnocie wyznacza ekonomię, a więc swoisty sposób, w jaki On, jedyny Zbawiciel, „dosięga poprzez ‘Ducha naszej egzystencji w swoistości jej bytowania. Kościól przyjmuje siebie i tym samym siebie wyraża $\mathrm{w}$ siedmiu sakramentach, poprzez które laska Boża wpływa konkretnie na egzystencję wiernych, aby całe ich życie, odkupione przez Chrystusa, stało się ofiarą miłą Bogu"30. W tym kontekście należy widzieć organiczną jedność wszystkich sakramentów

${ }^{26}$ Il Sobór Watykański, Dekret o postudze i życiu prezbiterów Presbyterorum ordinis, 5 (dalej: DK).

${ }^{27}$ Por. KK 1.

${ }^{28}$ Por. SacCar 16.

${ }^{29}$ Por. KK 9; 48.

${ }^{30}$ SacCar 16. 
i ich powiązanie z tajemnicą Eucharystii, z którą mają ścisły związek i ku niej zmierzają ${ }^{31}$.

Eucharystia, petnia chrześcijańskiego wtajemniczenia. Powiązanie sakramentów Kościoła z tajemnicą Eucharystii przede wszystkim uwidacznia się na drodze chrześcijańskiego wtajemniczenia. Stąd też, idąc za sugestią Benedykta XVI, trzeba postawić pytanie, czy we wspólnotach chrześcijańskich właściwie akcentuje się ścisłą więź chrztu, bierzmowania i Eucharystii? ${ }^{32}$ Pierwszy z tych sakramentów, czyli chrzest, stanowi niejako bramę dla wszystkich sakramentów i w konsekwencji wszczepia nas w Chrystusa, czyni członkami Kościoła i dziećmi Boga. Poprzez ten sakrament, jak powie św. Paweł, jesteśmy włączeni w jedno Ciało Chrystusa (por. 1 Kor 12,13). Jednak dopiero pełny udział w Ofierze eucharystycznej udoskonala w nas to, co otrzymaliśmy we chrzcie. Podobnie też i dar Ducha Świętego, którego otrzymujemy w sakramencie bierzmowania, ma służyć budowaniu Ciała Chrystusa. Moc Ducha Świętego, Jego charyzmaty, są potrzebne również do tego, by dawać świadectwo w świecie ${ }^{33}$. Nieprzypadkowo więc Eucharystia prowadzi do pełni chrześcijańskiego wtajemniczenia i stanowi ośrodek i cel całego życia sakramentalnego ${ }^{34}$.

Z pewnością przyjęcie sakramentu chrztu, bierzmowania i przystąpienie po raz pierwszy do Eucharystii są momentami decydującymi dla osoby, która zostaje wprowadzona w tajemnicę Kościoła, a przez jego posługę w tajemnicę samej Trójcy Świętej. To wydarzenie powinno być ważne także dla rodziny oraz lokalnej wspólnoty kościelnej. Jak zauważa to Benedykt XVI, całe „chrześcijańskie wtajemniczenie jest drogą nawrócenia, którą podejmuje się z pomocą Bożą i w ciągłym odniesieniu do wspólnoty kościelnej, czy to w przypadku doroslego, który prosi o przystąpienie do Kościoła (...), czy to w przypadku rodziców, którzy proszą o sakramenty dla swych dzieci"35. Wspomniany kontekst zwraca uwagę na zależność obecną pomiędzy chrześcijańską inicjacją a rodziną. Stąd tak ważne jest, by we wtajemniczenie nowego czlonka wspólnoty kościelnej

${ }^{31}$ Por. II Sobór Watykański, Konstytucja o liturgii świętej Sacrosanctum concilium, 10.

${ }^{32}$ Por. SacCar 17.

${ }^{33}$ Por. II Sobór Watykański, Dekret o misyjnej dzialalności Kościola Ad gentes, 9; 13.

${ }^{34}$ Por. SacCar 17; por. także: Jan Pawel II, List apostolski Dominicae Cenae (24.02.1980), 7: AAS 72 (1980), 124-127; DK 5.

${ }^{35}$ SacCar 19. 
angażować rodzinę, która winna być wspierana przez wszystkie wspólnoty kościelne. Należy w tym miejscu podkreślić wagę Pierwszej Komunii św., która dla wielu wiernych pozostaje na zawsze w pamięci jako pierwszy moment, w którym odczuli wagę osobistego spotkania z Jezusem ${ }^{36}$.

Sakrament pojednania. Więź Eucharystii i sakramentu pojednania przejawia się zarówno w odniesieniu do każdego ochrzczonego czlonka wspólnoty kościelnej, jak i do całej społeczności wierzących. Osobisty grzech człowieka oddziela go od Boga i wprowadza pewien rozdźwięk we wspólnocie, do której on należy. Stąd też sakrament pojednania i Eucharystia znajdują swój pelny wyraz w indywidualnym i wspólnotowym odniesieniu. Wspólczesny chrześcijanin zanurzony jest w kulturze, która zmierza do zanegowania poczucia grzechu ${ }^{37}$. Sprzyja to postawie zapominania o konieczności trwania w łasce Bożej, aby móc godnie przystąpić do sakramentalnej Komunii ${ }^{38}$. Nie dziwi więc fakt, Benedykt XVI zauważa, iż zagubienie świadomości grzechu prowadzi do spłycenia pojmowania miłości samego Boga. Ważne jest więc ponowne zwrócenie uwagi na te momenty Mszy św., które $z$ jednej strony przypominają o własnej grzeszności, z drugiej zaś o milosierdziu Boga ${ }^{39}$. Prawdziwe pojednanie staje się źródłem przywrócenia pełnej komunii kościelnej, czego wyrazem jest ponowne przystąpienie do Eucharystii ${ }^{40}$.

Namaszczenie chorych. Biblijne podstawy tego sakramentu znajdujemy w Liście św. Jakuba, który potwierdza obecność tego sakramentalnego znaku w pierwszej wspólnocie chrześcijańskiej (por. 5,14-16). Ewangelie wielokrotnie ukazują Jezusa jako lekarza ciał i dusz - Tego, który uzdrawia z dolegliwości i chorób, przywracając

${ }^{36}$ Por. tamże.

${ }^{37}$ Por. Jan Paweł II, Posynodalna adhortacja apostolska Reconciliatio et Paenitentia (2.12.1984), 18: AAS 77 (1985), 224-228 (dalej: RetP).

${ }_{38}^{38}$ Por. KKK 1385.

${ }^{39}$ Por. SacCar 20. Benedykt XVI jako przykład podaje słowa kapłana i odpowiedź zgromadzenia przed przystąpieniem do komunii: "Panie, nie jestem godzien, abyś przyszedł do mnie, ale powiedz tylko słowo, a będzie uzdrowiona dusza moja" (MR, s. $375^{*}$ ). Na uwagę zasługuje także modlitwa kapłana wypowiadana cicho przed zaproszeniem wiernych do komunii sakramentalnej: „Wyhaw mnie przez najświętsze Ciało i Krew Twoją od wszystkich nieprawości moich i od wszelkiego zła; spraw także, abym zawsze zachowywal Twoje przykazania i nie dozwól mi nigdy odłączyć się od Ciebie" (tamże).

${ }^{40}$ Por. SacCar 20; por. także KK 11; RetP 30. 
ludziom upragnione zdrowie. Misję uzdrawiania Jezus zleca również swoim apostołom (por. Mt 10,8; Łk 9,2; 10,9). Szukając wspólnej płaszczyzny sakramentu Eucharystii i namaszczenia chorych, trzeba najpierw zauważyć, iż w Eucharystii cierpienie i śmierć Chrystusa zostają przemienione w miłość. Natomiast namaszczenie chorych jednoczy ,cierpiącego z ofiarą, jaką Chrystus złożył z samego siebie dla zbawienia wszystkich, tak by i on mógł również w tajemnicy świętych obcowania uczestniczyć w zbawieniu świata"

Katechizm Kościoła Katolickiego ukazuje związek pomiędzy tymi sakramentami również wtedy, gdy stan zdrowia chorego się pogarsza: „Tym, którzy kończą swoje ziemskie życie, Kościół poza Namaszczeniem chorych ofiaruje Eucharystię jako wiatyk" "2. Najświętszy Sakrament, jako pokarm na drogę do domu Ojca, objawia się jako zadatek życia wiecznego i moc Zmartwychwstania! „Kto spożywa moje Ciało i pije moją Krew, ma życie wieczne, a Ja go wskrzeszę w dniu ostatecznym" (J 6,54). Swięty wiatyk odsłania więc przed chorym pelnię tajemnicy paschalnej, a także przynosi korzyść duchową całej wspólnocie kościelnej, która w ten sposób realizuje Jezusowe zapewnienie, że to, co uczyniono najmniejszym, uczyniono Jemu samemu (por. Mt 25,40) ${ }^{43}$.

Sakrament kaptaństwa. Szukając wewnętrznego związku między Eucharystią a sakramentem kapłaństwa, trzeba przywolać wydarzenie z Ostatniej Wieczerzy, wyrażone przez Jezusa: „To czyńcie na moją pamiątkę" (Lk 22,19). Ustanowienie Najświętszego Sakramentu w dzień przed męką pociągnęło za sobą ustanowienie kapłaństwa Nowego Przymierza. Chrystus, konstytuując Nowe Przymierze, stał się kapłanem, ofiarą i ołtarzem, jednym słowem: pośrednikiem pomiędzy Bogiem Ojcem i ludem (por. Hbr 5,5-10). Wypowiadane nad chlebem slowa: „to jest Cialo moje” i nad winem: ,to jest kielich Krwi mojej” otrzymują swoją nadprzyrodzoną moc dlatego, że są wypowiadane w imię i w zastępstwie Chrystusa jedynego, najwyższego kapłana nowego i wiecznego Przymierza in persona Christi (por. Hbr 8-9) ${ }^{44}$.

${ }^{41}$ SacCar 22.

${ }^{42}$ KKK 1524.

${ }^{43}$ Por. SacCar 22.

${ }^{44}$ Por. SacCar 23. Benedykt XVI przywołuje w tym miejscu Dokument o kaplaństwie ministerialnym Ultimis temporibus (30.11.1971) II Zgromadzenia Ogólnego Synodu Biskupów: AAS 63 (1971), 898-942, a także Posynodalną adhortację apostol- 
Benedykt XVI, przywolując niektóre wątki dotyczące związku pomiędzy sakramentem Eucharystii i sakramentem święceń, zwraca uwagę na osobę kapłana jako szafarza Najświętszego Sakramentu. Kościół przypomina w swym nauczaniu, że święcenia kapłańskie są koniecznym warunkiem, by Eucharystia była ważnie celebrowa$\mathrm{na}^{45}$. Naukę tę podejmuje Katechizm Kościoła Katolickiego, gdy wskazuje na osobę wyświęconego kapłana, w którego służbie eklezjalnej obecny jest w swoim Kościele sam Chrystus - jako Glowa swojego Ciała, jako Pasterz swojej trzody i Arcykapłan odkupieńczej Ofiary. Wyświęcony kapłan sprawuje swój urząd także w imieniu całego Kościoła, gdy zanosi do Boga modlitwę wspólnoty kościelnej, zwłaszcza zaś gdy składa Ofiarę eucharystyczną ${ }^{46}$.

Tak pojęta rola kapłana winna kształtować jego tożsamość, naznaczoną pokorną slużbą Chrystusowi i Jego Kościołowi. Stąd też posługa kapłańska powinna na pierwszym miejscu stawiać Chrystusa, który stanowi centrum celebracji liturgicznej. Kapłan winien stawać się coraz bardziej sługą i znakiem jednoznacznie wskazującym na Chrystusa. Jak podkreśla adhortacja, ujawnia się to szczególnie „w pokorze, z jaką kapłan przewodzi liturgii, w posłuszeństwie wobec obrzędu, służąc mu sercem i umysłem, unikając wszystkiego, co może sprawiać wrażenie niestosownego stawiania siebie na pierwszym miejscu" 47 .

Ważnym tematem, wspólcześnie żywo dyskutowanym, jest kapłański celibat, który tradycyjnie wiąże się z sakramentem święceń. Czy dzisiaj celibat niesie w sobie jakąś wartość? W kontekście Eucharystii kapłaństwo ministerialne domaga się pelnego upodobnienia do Chrystusa, jedynego i prawdziwego Kapłana. Celibat kapłański słusznie uważany jest za nieoceniony skarb, co potwierdza również wschodnia praktyka wybierania biskupów tylko spośród celibatariuszy. Wybór celibatu oznacza szczególne upodobnienie się kapłana do Chrystusa i oddanie się na wyłączną służbę Kościołowi, dla królestwa Bożego ${ }^{48}$. Patrzenie na celibat wyłącznie od

ską Pastores dabo vobis Jana Pawła II (25.03.1992), 42-69: AAS 84 (1992), 729-778 (dalej: PDV).

${ }^{45}$ Por. KK 10; Kongregacja Nauki Wiary, List o niektórych zagadnieniach dotyczqcych szafarza Euchanystii Sacerdotium ministeriale (6.08.1983): AAS 75 (1983), 1001-1009.

${ }^{46}$ Por. KKK 1548; 1552.

${ }^{47}$ SacCar 23.

${ }^{48}$ Por. SacCar 24. 
strony funkcjonalnej i administracyjnej nie jest wystarczające - wyraża on bowiem szczególne upodobnienie stylu życia kapłana do samego Chrystusa. Wybór ten ma charakter oblubieńczy i swoje najgłębsze źródło znajduje w Sercu „Chrystusa Oblubieńca, który daje życie dla swej Oblubienicy-Kościoła" ${ }^{\text {". }}$. Chrystus, wieczny Kaplan, potwierdzil swoją misję aż do ofiary Krzyża w stanie dziewiczym, co stanowi punkt odniesienia dla zrozumienia celibatu w tradycji Kościoła łacińskiego. Benedykt XVI, nawiązując do wielkiej tradycji kościelnej, do II Soboru Watykańskiego ${ }^{50}$ oraz do poprzednich papież ${ }^{51}$, potwierdza obowiązywanie celibatu w tradycji łacińskiej, podkreślając ,piękno oraz znaczenie życia kapłańskiego przeżytego w celibacie jako wyrazisty znak całkowitego i wyłącznego oddania Chrystusowi, Kościołowi oraz Królestwu Bożemu. (...) Kapłański celibat przeżyty w sposób dojrzały, z radością'i oddaniem jest ogromnym błogosławieństwem dla Kościoła i również dla całego społeczeństwa"s2.

Sakrament malżeństwa. Związek Eucharystii z sakramentem małżeństwa w najbardziej wyraźny sposób ujawnia się w określeniu, iż zarówno jeden, jak i drugi sakrament jest sakramentem mitości. Całe życie chrześcijańskie, jak zaznacza to Katechizm Kościoła Katolickiego, nosi znamię oblubieńczej miłości Chrystusa do Kościoła, np. chrzest, otwierając drogę do wspólnoty kościelnej, nowego ludu Bożego, wyraża tajemnicę zaślubin, wybrania i przygotowania do uczty weselnej, jaką jest Eucharystia ${ }^{53}$. Związek jaki istnieje między mężczyzną i kobietą, którzy są złączeni małżeństwem, jest obrazem związku istniejącego między Chrystusem-Oblubieńcem a Kościołem-Oblubienicą. Przypomina o tym Jan Paweł II, wskazując na pilną konieczność pogłębienia w naszych czasach tego wzajemnego odniesienia ${ }^{54}$. Eucharystia, jako sakrament miłości, wzmacnia jedność i nierozerwalną miłość każdego chrześcijańskiego małżeństwa. Wspólnota małżeńska na

\footnotetext{
${ }^{49}$ SacCar 24.

so Por. DK 16.

${ }^{51}$ Por. Jan XXIII, Encyklika Sacerdotii nostri primordia (1.08.1959): AAS 51 (1959), 545-579; Paweł VI, Encyklika Sacerdotalis coelibatus (24.06.1967): AAS 59 (1967), 657-697; PDV 29.

${ }^{52}$ SacCar 24.

${ }_{53}^{53}$ Por. KKK 1617.

${ }^{\$ 4}$ Por. Jan Pawel II, Posynodalna adhortacja apostolska Familiaris consortio (22.11.1981), 57 (dalej: FC); tenże, List apostolski Mulieris dignitatem (15.08.1988), 26.
} 
mocy sakramentu jest wewnętrznie scalona $\mathrm{z}$ jednością eucharystyczną Chrystusa i z Kościołem (por. Ef 5,31-32).

Wzajemne wyrażenie zgody małżeńskiej, która czyni z mężczyzny i kobiety wspólnotę życia i milości, ma wymiar eucharystyczny. Opierając się na teologii Pawlowej, Benedykt XVI stwierdza, iż „miłość małżeńska jest znakiem sakramentalnym miłości Chrystusa do swego Kościoła, milości, która ma swój punkt kulminacyjny w Krzyżu, który jest wyrazem Jego zaślubin z ludzkością, a zarazem źródłem i centrum Eucharystii"ss. Rodzina, zwana także domowym Kościołem $^{56}$, jest zasadniczą płaszczyzną życia Kościoła, głównie jeśli chodzi o chrześcijańskie wychowywanie dzieci. W tym kontekście należy widzieć szczególną misję kobiety w rodzinie i w społeczeństwie. Misji tej należy bronić, strzec oraz popierać ją, tak by kobieta, jako małżonka i matka, stawała się coraz bardziej godna najwyższego szacunku ${ }^{57}$.

- Istotnymi elementami sakramentu małżeństwa, łączącego się wieloma więzami z sakramentem Eucharystii, jest jedność małżeństwa oraz jego nierozerwalność. Zaznaczona mocno w dotychczasowych rozważaniach nierozerwalna i wyłączna więź, która łączy Chrystusa z Kościołem i która znajduje sakramentalny wyraz w Eucharystii, znajduje swój fundament w chrześcijańskiej antropologii, która zakłada, iż mężczyzna ma być złączony $z$ jedną kobietą, i na odwrót (por. Rdz 2,24; Mt 19,5) ${ }^{58}$. Podobnie wyrażona w Eucharystii nieodwołalność miłości Boga w Chrystusie względem Kościoła znajduje swoje odwzorowanie w sakramencie małżeństwa. Również tutaj dwoje ludzi winno - na wzór Chrystusa-Oblubieńca Kościoła - przyjąć i ofiarować sobie miłość, która zakłada nierozerwalność, a więc trwałość i wierność, aż do śmierci ${ }^{59}$.

Niestety, jak stwierdza adhortacja, współcześnie mamy do czynienia $\mathrm{z}$ prawdziwą plagą niszczącą wiele rodzin katolickich,

\footnotetext{
s5 SacCar 27.

${ }^{56}$ Por. KK 11.

${ }^{57}$ Por. Kongregacja Nauki Wiary, List o wspótpracy mężczyzny $i$ kobiety w Kościele iw świecie (31.05.2004): AAS 96 (2004), 671-687.

${ }^{58}$ Por. SacCar 28. Adhortacja podejmuje kwestię pracy duszpasterskiej w odniesieniu do tych, którzy spotykają się z głoszeniem Ewangelii, a pochodzą z kultur, gdzie praktykowana jest poligamia. Katechumenat ma pomóc w zrozumieniu pelnej prawdy o miłości, często wiążącej się z koniecznymi wyrzeczeniami, które mają dać nowym wiernym pełną komunię kościelną.

${ }^{59}$ Por. KKK 1640.
} 
a mianowicie: $\mathrm{z}$ rozwodami. Konieczna jest $\mathrm{w}$ tym względzie szczególna troska duszpasterska o tych, którzy po zawarciu sakramentu malżeństwa rozeszli się i zawarli nowy związek ${ }^{60}$. Benedykt XVI potwierdza praktykę Kościoła, zakorzenioną w Piśmie Świętym (por. Mk 10,2-12), niedopuszczania tych osób do sakramentów, gdyż swoim „stanem i sytuacją życiową obiektywnie sprzeciwiają się tej jedności w miłości pomiędzy Chrystusem i Kościołem, która jest oznaczona i realizowana w Eucharystii" ${ }^{61}$. Nie znaczy to jednak, że osoby rozwiedzione, które zawarły nowe związki, nie przynależą już do Kościoła. Nadal są one zobowiązane do prowadzenia chrześcijańskiego życia, m.in. do uczestniczenia we Mszy św. (choć bez przyjmowania Komunii św.), słuchania słowa Bożego, praktykowania adoracji eucharystycznej, modlitwy indywidualnej i wspólnotowej, czy też do praktykowania czynnej miłości, dzieł pokuty oraz troszczenia się o chrześcijańskie wychowanie swoich dzieci ${ }^{62}$.

Omawiając kwestię wzajemnych relacji panujących między Eucharystią a sakramentem małżenstwa, adhortacja zwraca dodatkowo uwagę na sytuacje, w których rodzą się uzasadnione wątpliwości co do ważności małżeństwa zawartego sakramentalnie. W tych przypadkach należy podjąć odpowiednie kroki w celu zweryfikowania zaistniałych trudności. Nieodzowne staje się postępowanie $z$ poszanowaniem prawa kanonicznego ${ }^{63}$, a więc zapewnienie obecności trybunałów kościelnych na danym terytorium wraz $z$ odpowiednią liczbą przygotowanych do tego osób, duszpasterski charakter trybunałów oraz ich poprawne i szybkie działanie. Należy przy tym pamiętać, iż podstawowym punktem spotkania prawa i duszpasterstwa jest mitość prawdy, która nie jest abstrakcyjna, ale przybiera konkretne kształty w ludzkim i chrześcijańskim życiu. Do rangi ważnego obowiązku, zdaniem Benedykta XVI, urasta staranie o to, aby tzw. działania instytu-

\footnotetext{
${ }^{60}$ Por. FC 84; Kongregacja Nauki Wiary, List do Biskupów Kościola katolickiego na temat przyjmowania Komunii św. przez wiernych rozwiedzionych, żyjacych $w$ nowych zwiazkach Annus Internationalis Familiae (14.09.1994): AAS 86 (1994), 974-979.

${ }^{61}$ SacCar 29.

${ }^{62}$ Por. tamże.

${ }^{63}$ Por. Papieska Rada ds. Interpretacji Tekstów Prawnych, Instrukcja odnośnie norm zachowania $w$ trybunalach kościelnych w kwestiach malzenskich Dignitatis Connubii (25.01.2005), Watykan 2005.
} 
cyjne Kościoła, prowadzone w trybunałach, stawały się coraz bliższe wszystkim wiernym ${ }^{64}$.

Wreszcie, gdy mamy do czynienia $z$ ważnym węzłem małżeńskim, a życie wspólne jest obiektywnie nieodwracalne, Kościół zachęca tych wiernych, aby kształtowali swój związek według wymogów prawa Bożego, a więc podjęli życie jako przyjaciele, jak brat i siostra. To pozwoli im ponownie przystępować do stołu eucharystycznego, stosować wymogi kościelnej praktyki i unikać w ten sposób jakichkolwiek wątpliwości, które mogłyby zrodzić się wśród wiernych co do wartości małżenstwa ${ }^{65}$. Powodem takiego działania jest świadomość Kościoła, iż sakramentalne małżeństwo jest wielkim dobrem dla Kościoła i spoleczeństwa. Małżeństwo i rodzina są instytucjami, które należy wspierać i bronić przed każdą możliwą dwuznacznością w pojmowaniu prawdy o nich, gdyż wyrządzona im szkoda jest poważnym naruszeniem podstawowych norm ludzkiej wspólegzystencji. Ciągle aktualne pozostaje wezwanie do odpowiedniego przygotowania narzeczonych - wraz z weryfikacją ich przekonań dotyczących zobowiązań wpływających na ważność sakramentu małżeństwa. Poważne potraktowanie tego zagadnienia z pewnością pomoże uniknąć wielu sytuacji, gdy „poruszenia uczuciowe i płytkie racje skłaniają dwoje młodych do podjęcia odpowiedzialności, której nie potrafią potem uszanować"ø6.

\section{Zakończenie}

Podsumowując analizę wybranych tematów zawartych w adhortacji apostolskiej Benedykta XVI Sacramentum Caritatis, dokonaną w świetle kanonu 897 Kodeksu Prawa Kanonicznego (1983) należy podkreślić troskę Kościoła o uświęcenie człowieka. Wiąże się ona w głównej mierze $\mathrm{z}$ działaniem Boga w sakramentach świętych, wśród których wyjątkowe miejsce zajmuje Eucharystia, określana jako Najświętszy Sakrament. Eucharystia jest tajemnicą wiary powierzoną Kościołowi, a jej wyjątkowe i niepowtarzalne znaczenie ma swoje źródło w tym, iż sam Chrystus Pan jest obecny w tym sa-

\footnotetext{
${ }^{{ }^{4} 4}$ Por. SacCar 29; por. także Benedykt XVI, Przemówienie do pracowników Trybunatu Roty Rzymskiej z okazji inauguracji roku sqdowniczego (28.01.2006): AAS 98 (2006), 138; „LOsservatore Romano” (wyd. pol.) 2006, nr 4 (282), s. 30.

${ }^{\circ 5}$ Por. SacCar 29.

« Tamże.
} 
kramencie. Jezus w Eucharystii ponawia swoją ofiarę dokonaną na krzyżu i staje się dla wszystkich wierzących pokarmem na życie wieczne. Obietnica Chrystusa dotycząca pozostania z uczniami aż do skończenia czasów realizuje się w Kościele, który dzięki Eucharystii żyje i ustawicznie wzrasta. Życie Kościoła, wspólnoty ludu Bożego, znajduje swój szczyt i źródło kultu w Eucharystii, a pozostałe sakramenty, ustanowione przez Jezusa i powierzone Kościołowi, żyją dzięki Eucharystii i ku niej są ukierunkowane.

\section{L'Eucaristia - il mistero della fede affidato alla Chiesa. L'esortazione apostolica di Benedetto XVI Sacramentum caritatis alla luce del canone 897}

Il Codice di Diritto Canonico (1983) dedica molti canoni alla funzione di santificare della Chiesa. Essa si realizza soprattutto attraverso i sacramlenti, tra cui l'Eucaristia occupa il posto provilegiato. Il Canone 897 parla dell'Eucaristia in modo sintetico e la definisce Santissimo Sacramento. L'esortazione di Benedetto XVI sull'Eucaristia Sacramentum Caritatis (2007) contiene numerosi motivi che rispecchiano il canone sopra menzionato. L'Eucaristia è un mistero della fede affidato alla Chiesa e trova il suo significato in Cristo Signore che è presente in questo sacramento. Egli stesso si offre in sacrificio spirituale al Padre nell'unità dello Spirito Santo e diventa cibo di vita eterna per gli uomini. La promessa di Cristo di restare con i discepoli fino alla fine del mondo si realizza nella Chiesa la quale vive e cresce grazie all'Eucaristia. Larticolo analizza, alla luce del canone 897, i temi presentati da Benedetto XVI nella prima parte dell'esortazione Sacramentum $\mathrm{Ca}$ ritatis. L'analisi viene fatta intorno ai seguenti punti: 1 . La dignità dell'Eucaristia. 2. Il mistero dell'Eucaristia. 3. LEucaristia - la vita della Chiesa. 4. L'Eucaristia ed altri sacramenti. 